\title{
BENEFITS OF OUT-OF-CLASS SPEAKING ACTIVITIES FOR EFL STUDENTS
}

\section{Abdullah COŞKUN*}

\author{
Geliş Tarihi: Nisan, 2016
}

\author{
Kabul Tarihi: Eylül, 2016
}

\begin{abstract}
The objective of the study is to investigate the benefits of out-of-class speaking activities for English as a Foreign (EFL) students. Twenty-one firstyear students in a state university in Turkey were encouraged to choose any out-of-class activities they would like to carry out for six weeks to improve their speaking skills. At the end of six weeks, they were given a survey of open-ended questions aiming to reveal the activities they selected and the perceived benefits of these activities. The chosen activities include the following: Fantasy Role-Playing, Continuous Story, Debate, Radio Program, Broadcasting on Periscope. As for the perceived benefits of these activities, nearly all the students indicated that their activities contributed to their fluency, vocabulary and pronunciation development as well as problem solving skills. Also, the activities were thought to be useful for their selfconfidence, critical thinking skills and for their general knowledge. Therefore, it can be recommended that out-of-class speaking activities should be incorporated into mainstream EFL programs.
\end{abstract}

Keywords: Out-of-class activities, English, speaking.

\section{SINIF DIŞI KONUŞMA ETKINLIKLLERININ INNGILIZZCE ÖĞRENENLER İÇIN FAYDALARI}

\section{Öz}

$\mathrm{Bu}$ çalışmanın amacı, sınıf dışı konuşma etkinliklerinin İngilizceyi yabancı dil olarak öğrenen öğrenciler için faydalarını incelemektir. Türkiye'de bir devlet üniversitesindeki 21 birinci sınıf öğrencisi, konuşma becerilerini geliştirmek için altı hafta boyunca yürütebilecekleri herhangi bir sınıf dışı etkinlik seçmeleri doğrultusunda teşvik edilmiştir. Altı hafta sonunda, öğrencilere açık uçlu sorulu, seçtikleri etkinlikler ve bu etkinliklerin algılanan faydalarını açığa çıkarmayı hedefleyen bir anket verilmiştir. Öğrencilerin seçtiği etkinlikler şu şekildedir: Fantastik Rol Yapma, Devam Eden Hikâye, Tartışma, Radyo Programı, Periscope'da Yayın. Bu etkinliklerin algılanan faydaları ile ilgili, neredeyse tüm öğrenciler etkinliklerin akıcı konuşmalarına, kelime ve telaffuz gelişimine ve problem çözme becerilerine katkı sağladığını belirtmişlerdir. Ayrıca, etkinliklerin kendine güven, eleştirel düşünme becerileri ve genel kültür açısından faydalı olduğu düşünülmüştür. Bu nedenle, sınıf dışı konuşma etkinliklerinin yaygın İngilizce programlarına dâhil edilmesi önerilebilir.

Anahtar Sözcükler: Sınıf dışı etkinlikler, İngilizce, konuşma.

\footnotetext{
* Assist. Prof. Dr.; Abant Izzet Baysal University, School of Foreign Languages, coskun_a@ibu.edu.tr.
} 


\section{Introduction}

Even though English has no official status in Turkey, it would be fair to state that Turkey is under the influence of the propagation of the English language around the world (Arik \& Arık, 2014). As indicated in the report written by TEPAV (Economic Policy Research Foundation of Turkey) and the British Council (2013), English is the most regularly used language in international communication in Turkey. It is also thought to be a necessity in the country for enhanced career opportunities and better job prospects. Moreover, it is highlighted in the report that knowing English even has an influence on Turkey's long-term economic growth potential. Despite the expansion and importance of English in the country, Turkey has recently been ranked 26th among 27 European countries in the "very low proficiency" category in the most recent edition of the EF English Proficiency Index (EF EPI) published by EF Education First (2015).

Among the many reasons behind the low English proficiency level in the country, one of the most important reasons might be that in contexts such as Turkey where English is spoken as a foreign language, the classroom is the only place where students get exposed to the language. As students only rely on classroom instruction in EFL contexts (Xiao \& Luo, 2009), it is argued that more efforts need to be made to encourage students to use the language beyond the classroom walls (Vaughan, Nickle, Silovs, \& Zimmer, 2011). Therefore, it can be suggested that out-of-class learning is a necessary complement to mainstream EFL programs, and being exposed to the target language outside the classroom is considered among the most important qualities of an effective language learner (Dörnyei \& Skehan, 2003). As stated by Lai, Zhu and Gong (2015), out-of-class learning embodies an important context for successful language development. Successful language learners are generally engaged in different out-of-class language learning activities (Lai \& Gu, 2011), and as Nunan (1991) claims, successful language learning in a variety of contexts all over the world is often associated with the learners' ability to continue learning English outside the classroom.

Out-of-class learning is generally described as any kind of learning occurring outside the classroom and can be categorized into three groups, which are as follows: self-instruction (i.e., learners locate sources to improve the language), naturalistic language learning (i.e., learners learn to communicate with the target language group incidentally), and self-directed naturalistic language learning (i.e., learners create a language learning situation) (Benson, 2001). Sundqvist (2009, p. 190) coined the term Extramural English to refer to "...linguistic activities in English that learners do or are involved in outside the classroom in their spare time". 
Many opportunities can be used or created by EFL learners to develop their basic language skills outside of the classroom. Online learning environments, such as blogs and Wikis (Kern, 2006), novels (Pickard, 1996), watching television (Brooks, 1992), reading newspapers (Hyland, 2004), listening to music (Jourdain, 1998) and even mobile phones (Şad, 2008; Saran, Seferoğlu \& Cağıltay, 2009) are only a few examples of English learning opportunities outside the classroom.

Underlining the importance of extracurricular language learning opportunities, Lightbown and Spada (2003) argue that in settings other than the classroom, the foreign language is learned naturally. Likewise, Stoller (2002) states that out-of-class language learning increases cooperation and motivation, and thus enhances students' confidence and self-esteem. In the same vein, Hyland (2004) suggests that foreign languages can be learned and practiced in any place and at any time outside the classroom context.

Furthermore, many second language acquisition (SLA) researchers favor the role of informal environments in the language learning process (Seliger, 1977; Krashen, 1985; Long, 1996; Ellis, 1997). For instance, it is claimed that the aim of language teaching is to enable students to use the target language not only in the classroom but also in the real world (Krashen \& Terrell, 1983). Similarly, Krashen (1985) argues that meaningful exposure to the target language both in formal and informal linguistic contexts is necessary for SLA. In addition, Gairns and Redman (1986) offer that engaging in out-of-class language learning enables both the retention of items previously learned and the acquisition of new items.

Considering the benefits of extracurricular language learning as mentioned above, outof-class learning activities are considered necessary for learners to reinforce what has been learned in the classroom (Stoller, 2002). By means of such activities, students can move beyond the traditional EFL classroom (Foss, Carney, McDonald, \& Rooks, 2007), and can connect what they have already learned with real life learning opportunities providing authentic language input (Pearson, 2004). Therefore, the present study examines first-year university students' outof-class activities and the perceived benefits of these activities.

\section{Literature Review}

In the literature, it was generally found that English proficiency and out-of-class learning are correlated with each other (Olsson, 2012). Out-of-class learning activities such as playing computer games (Uuskoski, 2011), using technologies such as Skype and podcasting in English (Godwin-Jones, 2005) as well as watching TV programs and films (Webb \& Rogers, 2009) positively affect English learners' proficiency levels. In addition, the following activities 
can be listed as beneficial out-of-class learning activities: reading books, newspapers, or magazines, surfing the Internet, chatting online, and listening to music with English lyrics (Sundqvist, 2009). Presenting recent and comprehensive case studies from a wide range of language learning contexts, Nunan and Richards (2015) also provide supportive evidence about the benefits of language learning outside the classroom.

There have been many studies focusing on out-of-class foreign language learning in different parts of the world. For instance, in an experimental study involving a control and an experimental group, Elley and Mangubhai (1983) studied the influence of extensive reading on children. They found that children who did extensive reading showed better progress in receptive skills (i.e., reading and listening) than the control group. On the other hand, a study carried out by Piirainen-Marsh and Tainio (2009) focused on teenagers playing video games. They explored the effects of video games on their language learning process and came to the conclusion that the games gave players the opportunity to practice their English as well as listen to different accents of English. In Nunan's (1989) study, most of the students thought that solely classroom instruction was insufficient for the improvement of their English proficiency, and believed in the merits of engagement in out-of-class learning environments.

Another study dealing with the use of English outside the classroom was carried out by Knight (2007). She discovered that the learners in her study participated in both individual and cooperative activities in English outside the classroom. It was also uncovered that there was a correlation between learners' outside classroom activities and their language proficiency. In another study, Spratt, Humphreys and Chan (2002) found that students' favorite activities such as using the Internet in English were mostly communicative and entertaining.

Exploring out-of-class activities of EFL students, Pickard (1996) concluded that students mostly preferred listening and reading activities involving receptive skills and neglected productive skills. In another study in which the researcher kept a diary to record her experiences in learning Spanish, Campbell (1996) revealed that socializing with both teachers and others had a profound effect on her language learning process. On the other hand, Suh, Wasanasomsithi, Short and Majid (1999) found that watching television and going to movies were regarded by their participants as the most beneficial activities that improved their speaking skills.

In a more recent study, Chan, Spratt and Humphrey (2002) collected data from students in an English program at a university. Learners in the study indicated that they frequently used English out of the classroom, and the most popular activities they engaged in were watching movies, surfing the Internet and sending emails. Furthermore, Hyland (2004) collected data 
from teacher trainees and teachers, and found that effective language learners could take part in various out-of-class English activities, such as writing emails and surfing the Internet. As a result, it was suggested that schools offering language classes should create out-of-class language learning opportunities for their students.

By studying the out-of-class activities of secondary school students, Yap (1998) discovered that students had the tendency to take part in receptive activities rather than activities dealing with productive skills. The participants in the study were found to have difficulty in creating opportunities for the practice of productive skills. Similar findings were reached in Littlewood and Lui (1996), and Ibadurrahman's (2012) studies. As out-of-class English speaking activities were found to be the least utilized activities in studies conducted in EFL contexts such as Turkey (Pickard, 1996; Yap, 1998; Hyland, 2004; Ibadurrahman, 2012), the present study aims is to investigate the benefits of out-of-class speaking activities practiced for six weeks by first-year university students striving to improve their speaking skills. At the end of these activities, students were given a survey including questions regarding their activities, the reason for choosing these activities, and the perceived benefits of their participation. Therefore, the following research questions were formulated:

1. What kind of out-of-class speaking activities were preferred by EFL students?

2. What are the perceived benefits of out-of-class speaking activities for EFL students?

\section{Methodology}

This study is a qualitative study based on open-ended survey questions dealing with the opinions of students on the benefits of out-of-class speaking activities they carried out for six weeks. Regarding open-ended questions, Dörnyei (2003, p. 47) claims that "...open-format items can provide a greater 'richness' than fully quantitative data". He also points out that through open-ended questions, participants' quotes can be obtained, and issues which were not previously anticipated can be revealed.

\section{Participants}

The participants of the study were first-year university students at the Department of English Translation and Interpretation in a state university in Turkey. The department offers a four-year B.A. program aiming to provide students with the necessary skills for a career in translation and interpretation. Twenty-one first-year students who opted to take part in out-ofclass extracurricular speaking activities were the participants of this study. 
Nine of the participants were male while the remaining 12 were female. Their age range was between 18 and 27. Some of these students obtained a passing score on the English proficiency exam administered by the preparatory English program to determine whether the language level of students was sufficient to follow their departmental courses in English, and thus were exempt from the program. On the other hand, some of the students attended a oneyear intensive English program before they were enrolled in the department.

Their English proficiency level was B2 according to the Common European Framework of Reference for Languages (CEFR). The reason why B2-level students were selected as the participants of this study is that a certain level of English is a necessity for English learners to be able to use English outside the classroom (Cheng, 2015).

\section{Data Collection and Analysis}

Volunteering participants were asked to freely choose and carry out a six-week speaking activity by coming together at least twice per week outside the class. Before the implementation of the activities began, the researcher met with all the students to collect their opinions regarding how frequently they would meet and how many students they could work with on the activities. After these issues and the activity ideas were agreed upon by both students and the researcher, the activities were initiated. During the six-week period, the researcher monitored the progress of the activities by conducting meetings with different group members.

After the activities ended, students received a survey with three open-ended questions dealing with their activity's description (Question 1: What was your activity?), the reason behind choosing the activity (Question 2: Why did you choose this activity?) and the perceived benefits of the activity (Question 3: Do you think the activity was beneficial? If yes, how?). The first two questions were answered by the group as a whole while the third question regarding the perceived benefits of the activity was answered by each member of the group separately.

In the next part of the study, a summary of students' activities is illustrated. Then, following a summary of the points brought up by the participants about the benefits of those activities, the responses of each student are presented. Participants' responses were not edited so as to retain their authenticity. Their responses related to the benefits of the activities were referred to with a number (e.g., Student 1: S1) in order to maintain anonymity.

\section{Results}

As evidenced in the table below, students worked in groups of three to seven. Five activities that can be named as follows emerged: Fantasy Role-Playing (FRP), Continuous Story, Debate, Radio Program, and Broadcasting on Periscope. While activities, such as Radio 
Program and Broadcasting on Periscope involve the use of technology, the remaining activities do not require technology use. As for the main reason for choosing the activities, the groups indicated that their activities could improve their speaking skills.

Table 1: Summary of Activities

\begin{tabular}{ll}
\hline Activity Description & Reason for Choosing This Activity
\end{tabular}

Fantasy Role-Playing $(N=7)$

Fantasy role playing is a game during which role players take the roles of fictional characters in a context whose rules are determined by group members.

Continuous Story $(N=4)$

The idea behind our activity is to develop a continuous story to create a hypothetical story in a group.

Debate $(N=4)$

We negotiated about current news and topics such as culture, health, different practices in different countries.

Radio Program $(N=3)$

Creating a Radio Program dealing with various topics, such as fashion and magazine content.

Broadcasting on Periscope ( $N=3)$

Our activity is about broadcasting live videos from our phones about various topics on Periscope, a social media platform.
This game urges every player to communicate with other players in English to solve problems.

There are no intervals while we are continuing conversation and it provides critical thinking, and fluent speech. It is also entertaining as well as educating.

We chose this activity because the topics we were discussing are current events. So group members generally have an opinion on these.

We could be all together with our friends in this activity. Also, that having a radio program would improve our speaking and conversation skills.

It is the best idea to speak more effectively.

\section{Perceived Benefits of Each Activity}

\section{Fantasy Role-Playing}

Seven students participated in the Fantasy Role-Playing activity, in which each player acted out the roles of different characters in a fictional context created by the group members. All of them thought that the activity was beneficial in terms of practicing unrehearsed speaking, solving problems, speaking English in a fun way, practicing acting skills, vocabulary and pronunciation development as well as critical thinking skills. The responses of each group member related to whether the activity was beneficial or not are as follows:

S1: The game which we played was useful for our English because it was interactive. This is very important for unrehearsed speaking. And we are planning to carry out this activity. I think we should do this more often in order to improve our English speaking skills. Sometimes I had some problems with talking but I believe I am better now.

S2: FRP is a unique experience urging every player to speak and act. Even an antisocial person can open up playing this game. I had more fun than I expected. As a group in the game, we tried to solve the problems working together. Each of us contributed to this game and 
the story. In the process of playing the game, we all spoke English. That way we created an English speaking zone.

S3: This activity forced us to speak, which I believe is the best way to improve your language skills in an entertaining atmosphere. Since it is not a lesson, it did not make us bored. It is just like playing a game and people improve their speaking skills without even realizing. People can play this game for hours.

S4: This game allows imagining yourself in certain circumstances and demands you to adapt to created environment while acting as if you were really living them in your mind. It also allows you to think as a character, which improves the individuals' strategic skills in the process. So it enhanced both my speaking and my acting.

S5: The activity improved my speaking and critical thinking skills.

S6: I learned new words from Old English because of the story in one of the FRPs and some fancy words I never heard before. While listening to my friends, I also realized that I used to mispronounce some words and used words inappropriately.

S7: The game improved my speaking skills and my imagination. I also learned different words from the other players. The brainstorming we made while playing the game helped us to learn new words.

\section{Continuous Story}

Four students took part in the Continuous Story activity, in which each member of the group added to the previous statement of his/her friend to make a story. Except for S1 who held the idea that the six-week implementation of the activity was not sufficient to get benefit from it, all the other participants argued for the benefits of the activity regarding their creativity, fluency and learning new vocabulary from their group friends.

S1: I can say that it only slightly improved my speaking skill because there was so little time to exercise for the speaking skill. I am of the opinion that if one seeks to improve speaking fluency, he/she must spend really long time on it.

S2: Despite the short span of time allocated for this activity, towards the end of the activity, I could feel that the time required for my brain to adopt the foreign language was obviously reduced. Moreover, this activity definitely improved my creativity. In each story we created, I had no idea what the next sentence would be. So I had to think every possible sentence that may come right after the one before. I forced my brain to be in the most creative 
way it could be. I sincerely believe that this activity was a huge opportunity for me to increase my speaking skills and vocabulary.

S3: To continue the stories, I had to think and speak fast. At first, it was difficult but as time passed by, I got used to it. I learned new vocabulary from my partners, too.

S4: I think this activity helped me a lot in terms of speaking and critical thinking. When we were making up the stories, we did not give any breaks to fulfill fluency. So we had to think what we were going to say quickly.

\section{Debate}

Four students engaged in group debates, in which they had discussions about issues such as cultural and other practices in different countries. The group members expressed their satisfaction with the activity outcomes highlighting that the activity enabled them to practice their English, feel more relaxed while speaking English, become familiar with news on the Internet, and learn new vocabulary items, and their pronunciation. Their comments are as follows:

S1: I think it was beneficial. If I continue practicing my English like that with either my friends or people I have never met before, my speaking skills will improve. We all talked about current issues about technology, culture, health and these issues were interesting to me.

S2: I feel that this activity contributed to my speaking skills. On the other hand, I kept informed of current news so my general knowledge increased, too. Also, this activity decreased my tension and uneasiness I experienced while speaking English. Additionally, I had a lot of fun during the activity.

S3: For this activity, we had the opportunity to do research and read news on the internet. I saw the other aspects of my ideas. This helped me improve my point of views. I made some pronunciation mistakes during the activity, but my friends helped me at this point.

S4: Since the topics we chose for the debates were different from each other, I could use varied words about topics. And actually when I used wrong words which were not suitable for the context or when I mispronounced a word, my friends helped me correct them.

\section{Radio Program}

Three students came together to create a radio program, during which each member of the group took a certain role (e.g., radio presenter, guest). All group members believed that the activity was beneficial in terms of gaining confidence and having natural conversations. Besides, S1 stated that the activity was useful as they searched and were informed of different 
news stories from around the world for their radio program. The perceived benefits of the activity from the perspectives of the group members are as follows:

S1: I learned a lot of new words as I had to search out the words I wanted to use for the program. With this activity, I feel myself more confident in speaking English. I also learned about different news from around the word as we discussed about some news of foreign countries.

S2: We, as a group, searched different topics to choose in our radio program. After speaking with my friends throughout the program for six weeks, I felt myself less under pressure while speaking.

S3: By doing a radio program, my group members and I learned to have a more natural conversation on a daily basis. Having conversations on different types of subjects helped us improve with our accent and it also helped with "talking without having to think in Turkish first."

\section{Broadcasting on Periscope}

Three students took part in the activity requiring the broadcast of videos on Periscope, a social media platform which allows users to share live videos using their smart phones. According to the students taking part in this activity, Periscope was useful as they could practice their English with people online and learn some daily language during their practices. However, it was indicated by S3 that there were only a few people responding to their videos and it would be more enjoyable if they had more people. Their comments are:

S1: Thanks to Periscope, I could reach more people, practice my English and learn some colloquial English. The activity was very helpful and amusing.

S2: The video we shared on Periscope gave us the chance to communicate with other people, learn from my friends and pick up new words I can use in daily life.

S3: I had some new friends on Periscope and had a chance to practice English with them. I will go on this activity. There were not many people who attended our broadcasts. If we had more people, it would be more fun and useful.

\section{Discussion of Findings}

In addition to revealing the preferred out-of-class speaking activities which were carried out twice per week for six weeks by first-year EFL students at a university in Turkey, the current study also aims to discover the benefits of these activities as perceived by the participating students. The analysis of their responses to open-ended questions led to the 
conclusion that Fantasy Role-Playing, Continuous Story, Debate, Radio Program and Broadcasting on Periscope were the activities they preferred.

The activities carried out by the participants in this study were all invented by the students themselves. The researcher only gave feedback when students needed help through the activities. When viewed from this aspect, it is fair to say that the researcher tried to give a sense of "power, responsibility and motivation to the learner" (Fornaciari \& Dean, 2014, p.703), which can be considered as an attempt to empower the students and help them become more independent learners.

In the Fantasy Role-Playing (FRP) activity, each member of the group represented certain characters by acting and speaking within the context of a fictional story. Regarding FRP, Cover (2010) states that players sit face-to-face, act out a role by developing characters based on certain rules set by the chief storyteller, and are also responsible for deciding what their characters do throughout the game. It is pointed out that role-playing games are beneficial for vocabulary development (Sylvén \& Sundqvist, 2012), and for the development of conversational language (Peterson, 2011). From Gee's (2008) perspective, the entertainment and pleasure experienced while playing games also facilitate language learning.

In the Continuous Story, on the other hand, each student produced a sentence relevant to the previous sentence uttered by the other group member to be able to complete an imaginative story. In his compilation of materials to boost students' speaking skills, Holmes (2004) also illustrates the implementation of such an activity by stating that each student adds a new sentence to continue the story meaningfully and creatively by going all the way around the circle towards the right.

The activity requiring debates about issues such as culture, each student in the group shared his/her opinions about the debated issue. Debating is considered an effective activity for foreign language learning because it increases argumentation skills and engages students in meaningful listening, speaking and writing practices (Krieger, 2005). The other group members who prepared a radio program took certain roles such as a radio reporter and a guest to talk about different news subjects throughout the radio program. As for radio programs, Stanley (2005) argues that creating a radio show is a popular means of improving English skills.

Within the scope of the activity Broadcasting on Periscope, a social media platform, the group members shared live videos about various topics on Periscope using their smart phones. Pertaining to Persicope, Digiday (2015), a modern media publication, states that Periscope gives users the opportunity to access a live stream and to interact with their audience in real 
time. Being a live video streaming application on smartphones, Periscope can also be regarded as a mobile learning tool. On the subject of mobile learning, Sharples (2006) claims that in recent years, the focus on mobile learning has shifted attention from formal classroom learning to informal out-of-class learning.

In addition to the above-mentioned creative out-of-class activities invented and carried out by students in this study, Richards (2015) draws attention to the following out-of-class language learning resources in his recent paper: chat rooms, self-access centers, language villages, e-mediated tandem learning, listening logs, digital media, digital games and television series. He also emphasizes that such out-of-class learning activities are plentiful in today's world, and thus should be used for language learning purposes.

In response to the survey questions regarding the benefits of the activities, students' reactions were generally found to be positive. As for the benefits of the Fantasy Role-Playing, it was thought that the activity was helpful in terms of practicing unprepared speaking, solving problems, practicing English in a fun way, acting skills, vocabulary and pronunciation development, as well as critical thinking skills. Regarding the Continuous Story, except for one participant who argued that the duration of the activity was not long enough to make an impact on their speaking skills, all the group members agreed that the activity contributed to their creativity, fluency and vocabulary development. Similarly, the Debate activity was perceived to be beneficial as it enabled participants to practice their English, feel more confident while speaking English, familiarize themselves with current news on the Internet, and learn new words and their pronunciation. As far as the Radio activity is concerned, the activity was regarded by the participants as helpful in gaining confidence and having natural talks. Finally, pertaining to broadcasting videos on Periscope, participants claimed that the activity gave them an opportunity to practice their English with people online and learn some colloquial English.

As can be realized from participants' responses, out-of-class foreign language learning opportunities offer many benefits to the language learner. The relevant literature also provides supportive evidence for the benefits of out-of-class foreign language learning (Pickard, 1996; Pegrum, 2000; Guo, 2011; Hyland, 2004; Godwin-Jones, 2005; Sundqvist, 2009; Webb \& Rogers, 2009; Uuskoski, 2011; Richards, 2015; Nunan \& Richards, 2015). For instance, Pegrum (2000) suggests that out-of-class foreign language learning leads students to become autonomous learners who can benefit from the language learning environment outside the classroom in their own time. Likewise, Richards $(2015$, p.1) argues that one of the two important dimensions to effective language learning is "what goes on outside of the classroom" while the other one is "what goes on inside the classroom." Regarding the out-of-class foreign 
language learning activities as illustrated in the present study, Stoller (2002) argues that such activities lead to student-centeredness, increase cooperation and motivation; therefore, it raises students' confidence, self-esteem, and autonomy.

To attract attention to the power of out-of-class foreign language learning, Richards (2015) gives an example of European countries where proficiency in English is very high (e.g., Finland) and moderately high (e.g., Italy) (EF English Proficiency Index, 2015). He justifies the difference between countries on the same continent by suggesting that English movies on TV and cinemas in the northern countries are shown in English with subtitles, whereas in other countries they are dubbed. According to Richards, even this anecdotal evidence shows the power of out-of-class exposure to comprehensible input in English. Similarly, Law (2007) associates out-of-class exposure to English with the success of countries with very high English proficiency (e.g., Netherlands, Sweden) when compared to countries with lower English proficiency (e.g., France and Spain).

\section{Conclusions and Implications}

Specifically regarding the Turkish EFL context, Soner (2007) argues that the English language teaching policy is not very successful in Turkey and justifies this situation by referring to many reasons including the lack of language learning opportunities outside the class. This problem applies to many other EFL contexts where students speak the same language and have limited exposure to the target language out of the classroom (Bresnihan \& Stoops, 1996). Therefore, there are certain actions which should be taken in order to expose students to English outside the classroom. By means of carefully planned training sessions, students at each level of education should be made aware that language is not a set of rules to know by heart; instead, as Benson (2001) indicates, it is something that students can be exposed to and learn incidentally outside the classroom.

Also, as recommended by Bell (2011), students who are involved in out-of-class learning activities can be rewarded to encourage other students to continue the language learning process outside the classroom. It is also argued that English teachers should enable learners to develop autonomous out-of-class English learning habits by leading them to the materials and activities which appeal to their interests (Cheng, 2015). Moreover, Richards (2015) suggests that English language teacher education programs need to be aware of the fact that effective teaching means preparing students for both in-class and out-of-class language learning; therefore, educating English teachers in line with this reality is an important requirement of current teacher training programs. 
In conclusion, as this study is limited to students' perceived benefits of out-of-class speaking activities they carried out for six weeks, it can only provide participants' subjective opinions. Therefore, experimental studies presenting statistical data about the English proficiency levels of English learners before and after they are engaged in out-of-class learning activities for a longer period of time should be carried out in future studies. As the participants of this study are high-proficiency students, it is suggested that future research should also investigate the opinions of low proficiency students regarding out-of-class language learning. Finally, more participants should be involved in future research studies, and learners' views about out-of-class reading, listening and writing activities should also be explored. Such future studies involving a larger student population with different proficiency levels can provide more convincing evidence for the benefits of out-of-class language learning both for different proficiency levels and for all the basic English language skills.

\section{References}

ARIK, B. T. \& ARIK, E. (2014). The role and status of English in Turkish higher education. English Today, 30(4), 5-10.

BELL, K. (2011). How ESL and EFL classrooms differ. Retrieved from https://oupeltglobalblog.com/2011/07/12/how-esl-and-efl-classrooms-differ/

BENSON, P. (2001). Teaching and Researching Autonomy in Language Learning. London: Pearson Education Limited.

BRESNIHAN, B. \& STOOPS, B. (1996). Three ways that work: oral fluency practice in the EFL classroom. Forum, 34(3), 30-46.

BROOKS, F. B. (1992). Communicative competence and the conversation course: A social interaction perspective. Linguistics and Education, 4(2), 219-46.

CAMPBELL, C. C. (1996). Socializing with the teachers and prior language learning experience: A diary study. In K. M. Bailey \& D. Nunan (Eds.), Voices from the language classroom: Qualitative research on language education (pp. 201-223). New York, NY: Cambridge University Press.

CHAN, V., SPRATT, M. \& HUMPHREYS, G. (2002). Autonomous language learning: Hong Kong tertiary students' attitudes and behaviours. Evaluation and Research in Education, 16(1).

CHENG, C. M. (2015). Perceptions of and Experiences with Vocational College English Majors' Out-of-class English Learning in Taiwan. Journal of Language Teaching and Research, 6(4), 737-748.

COVER, J. G. (2010). The Creation of Narrative in Tabletop Role-Playing Games. McFarland.

DIGIDAY. (2015). http://digiday.com/brands/5-ways-brands-using-periscope/

DÖRNYEI, Z. (2003). Questionnaires in second language research: Construction, administration, and processing. Mahwah, NJ: Lawrence Erlbaum. 
DÖRNYEI, Z. \& SKEHAN, P. (2003). Individual differences in second language learning. In C. J. Doughty \& M. H. Long (Eds.), The handbook of second language acquisition (pp. 589-630). Malden, MA: Blackwell Publishing.

EF Education First. (2015). EF EPI English proficiency index. Retrieved from http://www.ef.com.tr/epi/regions/europe/

ELLEY, W. B, \& MANGUBHAI, F. (1983). The Impact of Reading on Second Language Learning. Reading Research Quarterly, 9(1), 53-67.

ELLIS, R. (1997). Second Language Acquisition. New York: Oxford University Press.

FORNACIARI, C. J. \& DEAN, K. L. (2014). The 21st-century syllabus from pedagogy to andragogy. Journal of Management Education, 38(5), 701-723.

FOSS, P., CARNEY, N., MCDONALD, K. \& ROOKS, M. (2007). Project-based learning activities for short-term intensive English programs. Asian EFL Journal, 23, 1-19.

GAIRNS, R. \& REDMAN, S. (1986). Working with Words: A Guide to Teaching and Learning Vocabulary. Cambridge: Cambridge University Press.

GEE, J. P. (2008). Learning and games. The ecology of games: Connecting youth, games, and learning, 3, 21-40.

GODWIN-JONES, R. (2005). Skype and podcasting: Disruptive technologies for language learning. Language Learning \& Technology, 9(3), 9-12.

GUO, S. C. (2011). Examining the relationship between outside reading, reading habits, and reading speed. Paper presented at the First Extensive Reading World Congress, Kyoto, Japan.

HOLMES, D. (2004). Speaking Activities For The Classroom. Retrieved from http://www.noblepath.info/speaking/apeaking_activities.pdf

HYLAND, F. (2004). Learning autonomously: contextualizing out-of-class English language learning. Language Awareness, 13(3), 180-202.

IBADURRAHMAN, I. (2012). Out-of-class Language Learning Activities and Students' Achievement (A Case Study of Indonesian Students in a Senior High School, Bandung, Indonesia). Unpublished MA thesis, Postgraduate Program, IIUM.

JOURDAIN, R. (1998). Music, the brain, and ecstasy: How music captures our imagination. New York: Harper Collins.

KERN, R. G. (2006). Perspectives on technology in learning and teaching languages. TESOL Quarterly, 40(1), 183-210.

KNIGHT, T. L. (2007). Beyond the classroom walls: A study of out of class English use by adult community college ESL students. Unpublished MA thesis, Portland, Oregon: Portland State University.

KRASHEN, S. (1985). The Input Hypothesis: Issues and Implications. Longman: London and NewYork.

KRASHEN, S. \& TERRELL, T. (1983). The Natural Approach: Language Acquisition in the Classroom. Oxford: Pergamon.

KRIEGER, D. (2005). Teaching debate to ESL students: A six-class unit. The Internet TESL Journal, 11(2).

LAI, C. \& GU, M. Y. (2011). Self-regulated out-of-class language learning with technology. Computer Assisted Language Learning, 24, 317-335. 
LAI, C., ZHU, W. \& GONG, G. (2015). Understanding the quality of out-of-class English learning. TESOL Quarterly, 49(2), 278-308.

LAW, P. (2007). Why are the Dutch better than us at learning languages? Retrieved from http://keilem.com/ blog/2012/09/06/double-dutch/

LIGHTBOWN, P. M. \& SPADA, N. (2003). How languages are learned. Oxford: Oxford UP.

LITTLEWOOD, W. \& LIU, N. F. (1996). Hong Kong students and their English. Hong Kong: Macmillan.

LONG, M. H. (1996). Handbook of second language acquisition. New York: Academic Press.

NUNAN, D. (1989). Understanding language classrooms. New York, NY: Prentice Hall.

NUNAN, D. (1991). Language Teaching Methodology. Prentice Hall, London.

NUNAN, D. \& RICHARDS, J. C. (2015). Language Learning Beyond the Classroom. New York and Oxford: Routledge.

OLSSON, E. (2012). "Everything I read on the Internet is in English". On the impact of extramural English on Swedish 16-year-old pupils' writing proficiency. Göteborg: Gothenburg University.

PEARSON, N. (2004). The idiosyncrasies of out-of-class language learning: A study of mainland Chinese students studying English at tertiary level in New Zealand. Proceedings of the Independent Learning Conference, 2003.

PEGRUM, M. (2000). The Outside World as an Extension of the EFL/ESL Classroom. The Internet TESL Journal, 6(8).

PETERSON, M. (2011). Digital gaming and second language development: Japanese learners interactions in a MMORPG. Digital Culture \& Education, 3(1), 56-73.

PICKARD, N. (1996). Out-of-class language learning strategies. English Teaching Journal, 50, 150-59.

PIIRAINEN-MARSH, A. \& TAINIO, L. (2009). Other-repetition as a resource for participation in the activity of playing a video game. The Modern Language Journal, 93(2), 153-169.

RICHARDS, J. C. (2015). The Changing Face of Language Learning: Learning Beyond the Classroom. RELC Journal, 46(1), 5-22.

SARAN, M., SEFEROĞLU, G. \& CAĞILTAY, K. (2009). Mobile Assisted Language Learning: English Pronunciation at Learners' Fingertips. Egitim Arastirmalari-Eurasian Journal of Educational Research, 34, 97-114.

SELIGER, H. (1977). Does practice make perfect? A study of interaction patterns and L2 competence. Language Learning, 27, 263-278.

SHARPLES, M. (2006). Big issues in mobile learning. Report of a workshop by the Kaleidoscope Network of Excellence Mobile Learning Initiative. UK: University of Nottingham.

SONER, O. (2007). Türkiye'de yabanc1 dil eğitimin dünü bugünü. Öneri, 7(28), 397-404.

SPRATT, M., HUMPHREYS, G., \& CHAN, V. (2002) Autonomy and motivation: Which comes first? Language Teaching Research, 6, 245-66.

STANLEY, G. (2005). Podcasting for ELT. Retrieved from http://www.teachingenglish.org.uk 
STOLLER, F. (2002). Project Work: A Means to Promote Language and Content. In J. Richards \& W. Renandya (Eds.), Methodology in Language Teaching: an anthology of Current Practice (pp. 107-120). Cambridge: Cambridge University Press.

SUH, J. S., WASANASOMSITHI, P., SHORT, S. \& MAJID, N. A. (1999). Out of class learning experiences and students' perceptions of their impact on English conversation skills. Research report at Indian University. ERIC document no. ED433715.

SUNDQVIST, P. (2009) Extramural English matters: Out-of-school English and its impact on Swedish ninth graders' oral proficiency and vocabulary. Unpublished $\mathrm{PhD}$ thesis, Karlstad: Karlstad University Studies.

SYLVÉN, L. K. \& SUNDQVIST, P. (2012). Gaming as extramural English L2 learning and L2 proficiency among young learners. ReCALL, 24(3), 302-321.

ŞAD, S. N. (2008). Using Mobile Phone Technology in EFL Class. English Teaching Forum, 46(4), 34-39.

TEPAV \& British Council. (2013). Turkey national needs assessment of state school English language teaching. Retrieved from

http://www.britishcouncil.org.tr/sites/default/files/turkey_national_needs_assessm ent_of_state_school_english_language_teaching.pdf

UUSKOSKI, O. (2011). Playing video games: A waste of time...or not?- Exploring the connection between playing video games and English grades. Helsinki: Helsinki University Press.

VAUGHAN, N., NICKLE, T., SILOVS, J. \& ZIMMER, J. (2011). Moving to their own beat: Exploring how students use Web 2.0 technologies to support group work outside of class time. Journal of Interactive Online Learning, 10(3), 113-127.

WEBB, S. \& RODGERS, M. P. H. (2009). Vocabulary Demands of Television Programs. Language Learning, 59(2), 335-366.

XIAO, L. \& LUO, M. (2009). English co-curricular activities: A gateway to developing autonomous learners. CamTESOL Selected Papers, 5, 239-251.

YAP, S. L. (1998). Out-of-class use of English by secondary school students in a Hong Kong Anglo-Chinese school. Unpublished MA thesis, University of Hong Kong. 